\title{
A Plea for Teaching English as a Second/Foreign Language Through Its Native Speakers' Culture
}

\author{
Mohammad Almutairi ${ }^{1}$ \\ ${ }^{1}$ Language Center, College of Basic Education, the Public Authority for Applied Education and Training, Kuwait \\ Correspondence: Dr. Mohammad A. Almutairi, Language Center, College of Basic Education, The Public \\ Authority for Applied Education and Training, Kuwait. E-mail: motairi1968@gmail.com
}

Received: September 4, 2020

Accepted: October 5, $2020 \quad$ Online Published: November 16, 2020

doi:10.5539/ijel.v11n1p93

URL: https://doi.org/10.5539/ijel.v11n1p93

\begin{abstract}
This study aims to narratively investigate the rationale of the first school of thought that supports and pushes towards introducing native speakers' culture in the English language curriculum. It presents the researchers' arguments and justifications for this belief and its promotion. It also discusses their findings and the results from the empirical studies that they have conducted in different countries, which support their school of thought.
\end{abstract}

Keywords: language \& culture, TESOL, ELT, native culture

\section{Introduction}

Introducing foreign cultures in the English language curriculum has always been a great debate among researchers. While some consider it a must and a way to improve the language syllabus and the understanding of the foreign language, others see it as a Trojan horse, or a type of linguistic imperialism that would have a negative impact on ESL/EFL learners. In this respect, two school of thought have come to the surface. The first supports introducing the native speakers' culture into ESL /EFL textbooks, while the second rejects this prospectus and calls for replacing it with the host or a mixed international culture. In this study, the researcher describes the rationale and justifications of the first school of thought's supporters who are in favour of teaching EFL/ESL through the prism of native speakers' culture alongside some of their empirical studies.

\section{Methodology and Research Questions}

As this study tries to investigate and identify some researchers' reasons and justifications for teaching ESL/EFL through the prism of its native speakers' culture, the researcher will use the narrative method to review the literature on this crucial issue.

In other words, this study will try to find answers to the following questions:

1) What are the reasons and justification that lead some researchers to support introducing ESL/EFL to learners through the prism of native speakers' culture?

2) Which empirical studies support their perspective?

\section{Literature Review}

Many non-native speakers of English, who have the ability to understand individual, common words of the English language and its grammar become confused and sometimes get lost, especially when they travel to one of the English-speaking countries. Some researchers think that these situations might happen because of the lack of exposure to the NS's cultures. Robinson (1985), for example, proposes that one way to help EFL learners improve their communication in English is to expose them to the NS's cultures by introducing it in their classes. He also believes that reading about the NS's cultures could help these students improve their understanding of the beliefs, values, and interpretations of native speakers. Levy (2009), in her article 'Technologies in Use for Second Language Learning', expresses her support for exposing EFL and ESL learners to NSs' cultures and contacts if possible. She believes that this exposure could happen not only by the cultural content inside the course books but by technologies such as L2 websites, chats, discussion forums, wikis, and video conferencing, which will help in expanding the learners' horizons about the native speakers' cultures, especially for those who cannot afford travelling to such countries and living there for a period of time.

In the same vein, Seelye (1994) explains that learning words in isolation does not lead to understanding them in 
a larger context because isolated words can have many different meanings but rarely communicate much. She also believes that "only within a larger context do individual words mean anything precise enough for reasonably accurate communication" (p. 6). She argues further that without cultural background knowledge, non-native speakers with good command of language forms and vocabulary would find it difficult to understand things like street signs or public advertising. This difficulty actually happens to some Kuwaiti's language learners, especially when they travel to the UK and come across words or new behaviors such as shaking the hands of a lady if the learner is a man.

Even in class activities, it is not surprising that a female Muslim EFL learner does not often volunteer to lead a group when there are other Muslim male learners in the group. This is the consequence of her upbringing, which recognizes the leading role of a male Muslim. She will often avoid direct eye contact with male teachers when responding to a question as direct eye contact with a person of the opposite sex, is undesirable in the Islamic context, especially when they are not related (Syahrom, 1995).

Seely comments on this issue by stating that since language is primarily a social instrument, it cannot be isolated from the society that uses it. Hence, she criticizes the naive assumption that learning language rules would be enough to communicate with and understand native speakers. It is also very important to point out that among ELT specialists' teachers, scholars, and researchers, nobody believes this assumption and has not believed this since at least the 1980s. She as well believes that EFL learners must learn the language in the native speakers' cultures and learn what she calls "the cultural referents" which are necessary to understand a native speaker. Thus, according to her, without the knowledge of the cultural referents, one can find it difficult to appropriately communicate his or her message to a native speaker or may even send the wrong message, which will cause a misunderstanding. She elaborates by stating that learning the language structure alone does not guarantee learning the political, social, religious, or economic system necessary to build up the cultural background, which, in turn, is necessary for international communication.

Byram and Fleming (1998) argue that without sharing the same referential meaning of words, communication between speakers cannot be successfully achieved. Here, they agree with Seelye that it is not enough just to learn the linguistic structure and the vocabulary of the foreign language without knowing the 'cultural referents' of language shared by native speakers. Therefore, Byram and Fleming stress that language learners should learn the cultural shared meanings, values, and practices that are embodied in the language. Thus, they encourage language teachers to find new means to help learners go beyond learning the linguistic system to learn about the cultural dimension of the native speakers' language.

Regarding this issue, Bennett (1997) has a very interesting description for language learners who are aware of the language vocabulary and forms but are not aware of the language 'cultural referents'. He calls them 'fluent fools'. Bennett uses the concept of 'fluent fool' to define language learners who only learn the language forms and vocabulary without understanding its native culture and the people who use it. He believes that a fluent fool will face difficulties in communication in some social events with native speakers. This problem was also addressed by Pesola (1991), who stated, 'without cultural insight and skills, even fluent speakers can seriously misinterpret the messages they hear or read, and the message they intend to communicate can be misunderstood' (p. 331).

Misunderstanding of verbal or non-verbal messages could lead to the creation of a distorted picture of another society and its culture. A good example could be the following:

If a Polish person in the United States is offered a meal, he/she might express his/her polite refusal because it is a sign of modesty. He/she expects that the American should ask him/her again to take the meal. Instead, the Polish person could be unpleasantly surprised to be given nothing to eat and might even think that Americans are stingy with food. The American host would not realize that refusing food is a sign of modesty, and the person offering the meal should insist.

A German person having a meal with a Taiwanese might not understand that belching at the food table is a kind of a compliment for the cook and instead might feel disgusted. The Taiwanese family, on the other hand, would probably recognise the German's reaction (lack of belching) as an impolite behavior.

If a Kuwaiti person is asked, "How are you?" by a Briton, he/she might complain about his/her health and start talking about sickness. This could make the Briton wonder why he/she hears this answer because he/she expects to hear a different answer.

Language 'foolishness' might be a result of what Hendon (1980) referred to as 'attaching the wrong meaning to the foreign words. For example, in Egypt, the meaning of the word Friday is not the same in English. It means 
(the period of seven days), for this reason, if an Egyptian says, 'I have not seen Mr X since Friday,' he/she means that he/she has not seen him for a total of seven days.

Emphasising the inseparability of language and culture, Hendon commented that we cannot teach EFL in isolation of its native-speaking cultures. She also added that, without exposure to the NS's cultures, EFL teachers would merely teach words with no cultural dimension. As a result, as she explained, learners would attach the wrong meanings to these words; that is, they would attach their own cultural meaning to the foreign words. She remarked, 'If we teach a foreign language without introducing at the same time the culture in which that language operates, we are merely conveying words to which the student attaches the wrong meaning, for unless students understand the underlying cultural image of the word, they will attach American images to the foreign word' (p. 192). For example, if a salesman in a supermarket in the USA says the phrase 'cash or credit?' to a client, it means: 'Would you like to buy the item by cash or by a Visa card?' In Kuwait, however, the phrase 'cash or credit?' is different because it means: 'Would you like to buy the item by cash or by monthly installments?'

In this instance, Hendon would argue that without exposure to the native speakers' cultures, foreign language learners would not be able to understand the social/cultural behaviors of the people of the native speakers' language, which, in turn, can result in miscommunication. A good example could be the image of the dog in native-speaking countries, which is totally different from its image in the Muslim countries. In the native-speaking countries, the dog is the family's most loyal friend. It has rights as part of the idea that all animals have rights, and it has all the possible facilities such as shelter, food and so on. On the other hand, in the Muslim world, people are not allowed to own a dog except for security purposes because Muslims have a belief that if the dog enters a house, the angels of Allah will not enter the house. I remember that in 1989, one of my Kuwaiti friends was studying in a language school in Portsmouth and staying with an English family which had a dog in the house. When they gathered for breakfast, the dog came across my friend, who shouted into the face of the dog to keep it away from his dish. The family was very angry, and my friend moved to another family which had no pets. This miscommunication resulted because of the lack of exposure to the NS's cultures.

To avoid turning out fluent fools, Bennett recommended that language teachers make sure that students understand the cultural dimensions of the language they are learning in addition to practicing reality. In his explanation for experiencing reality, he states:

To avoid becoming a fluent fool, we need to understand more completely the cultural dimension of language. Language does serve as a tool for communication but is also a "system of representation" for perception and thinking. This function of language provides us with verbal categories and prototypes that guide our information of concepts and categorizations of objects; it directs how we experience reality (p. 16).

In other words, because language teaching for Bennett is also reality teaching, ESL/EFL teachers should provide their learners with the linguistic construction which includes guidelines of how to practice reality in a different way. Bennett first discovered practicing reality and other dimensions of the language when he was an ESOL teacher in the Micronesian islands of Truk. Bennett explains that when he was teaching his EFL students colors by using a board which has the question 'I see a __ ball', but when it came to the green color, his students became confused. When he showed them the blue color, the same thing happened. The students could pronounce the words, but they could not recognize the differences between the two colors. In their language, they use the same word, 'arow', for both 'green' and 'blue'. 'Arow' is the answer to both questions: 'What color is the sea?' and 'What color is the grass?'

Bennett adds that while he was teaching them English (the lesson of colors), he was also teaching them how to experience something new and real (the difference between blue and green) that they did not experience using their own language.

Taking a similar stance, Byram and Risager (1999) argued that when a teacher teaches a foreign language, he or she teaches not only linguistic forms but also a different means of interpreting the experience of reality. They described entities that originated in one context that are more appropriately expressed by the language of that context.

Regarding this point, Bennett expresses that the counting system can differ and leads to different experiences of reality. For example, the native language has one counting system, which is one, two, three, et cetera; whereas in Japanese, noun classifiers are used for different groups of nouns according to the size, shape, texture, material, or purpose of an object, which is quite different and separate from counting. 
These problems might not be widespread in the world but can be good examples of experiencing reality. Bennett, as a result, urged language teachers to expose their students to the cultural dimension of the NS's cultures so that they experience reality in new ways and avoid appearing foolish.

In the same regard, both Bennett (1997) and Byram and Risager (1999) supported Seelye's (1994) argument about the perception of reality. Seelye argued that with respect to how different people from different cultures perceive things around them, different cultures perceive cultural themes like colors, kinship relationships, space, and time differently based on their linguistic and cultural background. For example, she described that 'feeling blue' does not always mean 'sad'; for Brazilians, feeling 'blue' means feeling 'great'.

Barro et al. (1993) argued that policy statements and curricula in many countries reflect the stance that foreign language teaching should aim at educating young people to become global citizens who can function in different cultures. However, Barro et al. (1993) indicated that the fallacy of perception that language and culture are separable in Singapore had led to less emphasis on teaching the NS's cultures and exposing students to the native speakers' cultural behaviours and perspectives. They stated that this separation is unfortunate for two reasons:

1) Without insight and understanding of the NS's cultures and their cultural and social practices, a learner of a foreign language will have difficulties communicating with native speakers due to a lack of cultural background knowledge that native speakers share.

2) Developing practical skills in the foreign language cannot be assumed to lead to the development of an understanding of the NSC perspectives (pp. 56-57).

Abdullah and Chandran (2009) think that there is general tacit approval among some language researchers about the importance of the role of the target (native speakers') cultures in EFL/ESL, which would result in acculturation; this, in turn, would encourage communicative competence among ESL/EFL learners. They claim that cultural understanding should not be ignored by educationalists but that they should be at the heart of foreign language learning.

For them, introducing the target (native speakers') cultures to EFL/ESL learners is the best solution for helping them to become competent communicators, as they state: 'learning the linguistics of a language involves assimilating cultural associations and all its cultural load. A learner then avoids all the pitfalls of cultural misunderstanding or ignorance, which leads to the breakdown of communication' (p. 4).

Furthermore, they believe that becoming competent in a foreign language cannot be achieved without a cultural understanding of the foreign language as it is the core of language acquisition. This is shown in the fact that when a learner decides to learn a language, such as German, they are not only learning German linguistics but everything else German and related to Germany. Thus, in addition to communication, learners who claim to have acquired a foreign language are 'those who are able to align themselves with the culture of the target language' (p. 4).

Le (2002) asserts that it is not possible to separate language from its culture, and therefore, it is essential to combine the teaching of a language with the 'culture of the target language.' He goes beyond that it is impossible to learn a new language without learning its culture. First, he proposes that learning vocabulary items in isolation does not lead to understanding them when used in larger situations because isolated vocabulary might have different meanings but rarely communicate much. Second, he believes that teaching English without introducing the target culture could cause what he calls 'cultural shock' among EFL/ ESL learners. This cultural shock could negatively affect their ability to learn the foreign language. He affirms that learners' attitudes toward the second language are a crucial factor affecting their success or failure in learning the second language.

Le adds that when EFL Vietnamese students travel to study English in native-speaking countries, such as Australia, they face that 'language shock' when first dealing with some unexpected and very challenging aspects of the English language, such as the existence of irregular verbs and the rules of article usage. He gives an example that Vietnamese EFL students in Australia discover that Australian students normally call their professors by their first names. Such students may find it very difficult to adapt to this situation, and it could be the cause of ongoing discomfort. In this respect, Furnham and Bochner (1986) think that the experience of a new culture could be potentially confusing and disorienting for people, including EFL learners and that the greater distance between the host culture and the foreign culture, the more cultural difficulty the overseas students would experience.

Le's belief is supported by Morgan (1993) where, in her article 'Attitude Change and Foreign Language Culture Learning', she quotes Byram (1989) as saying that it is not possible to separate language from culture and that as a new language is learned, so is the culture of that language. 


\subsection{Empirical Studies}

In Greece, Prodromou (1992) conducted an interesting study to investigate adult Greek ESL learners' attitudes and preferences towards which culture should be presented in their ESL learning classrooms: (host or NS's cultures: American or British) and which model they prefer to learn their ESL (British English or American English). For the purpose of his study, he distributed 300 questionnaires among his students.

The results of his study showed positive attitudes among ESL learners towards the NS's cultures. However, when in-depth analysis of the data towards which NS's cultures they preferred, the analysis showed that $75 \%$ of participants were in favor of learning ESL through the British culture or the model of British English, while (18\%) preferred learning ESL through the American culture. Prodromou claims that having this high percentage towards the British culture could be a result of the overall popularity of British English in the world, whereas the low percentage towards the American English could be due to the relative lack of historical relations between Greece and the USA.

This positive attitude of students towards native speakers' cultures and norms is similar to the results of Timmis's (2002) study. In his very important study regarding teachers' and students' attitudes toward native speakers' norms, Timmis collected his data by distributing questionnaires to 400 students from 14 countries and 100 teachers from 45 countries. The findings of the study showed that students' views were different from the teachers' views. While teachers wished to move away from native speakers' norms, students, in contrast, wished to conform to native speakers' norms.

\section{Conclusion}

From the above review of the literature discussing the importance of introducing ESL/EFL to ESL/EFL learners through the native speakers' culture, it is concluded that this issue should get more consideration when designing the curriculum of English language education, especially where ESL/EFL is introduced through the local and host culture such as in the Arabian Gulf countries. For this reason, researchers must continue to create further studies in order to recognize the real relationship between ESL/EFL and culture and develop and enhance foreign language teaching.

\section{References}

Abdullah, N., \& Chandran, S. (2009). Cultural elements in a Malaysian English language textbook. A paper presented at the Islamic Science University of Malaysia (USIM), March 2009.

Barro, A., Byram, M., Grimm, H., Morgan, G., Roberts, C., \& Valley, T. (1993). Cultural studies for advanced language learners. In D. Graddol, L. Thompson \& M. Byram (Eds.), Language and culture (pp. 55-70). Philadelphia: Multilingual Matters Ltd.

Bennett, M. (1997). How not to be a fluent fool: Understanding the cultural dimension of language. In A. Fantini (Ed.), New ways in teaching culture (pp. 16-21). Alexandria, VA: TESOL Publications.

Byram, M., \& Fleming, M. (1998). Language learning in intercultural perspective: Approaches through drama and ethnography. Cambridge, UK: Cambridge University Press.

Byram, M., \& Risager, K. (1999). Language teachers, politics, and cultures. Philadelphia. Multilingual Matters.

Furnham, A., \& Bochner, S. (1986). Culture shock—psychological reactions to unfamiliar environments. London: Taylor \& Francis.

Hendon, S. (1980). Introducing culture in the high school foreign language classes. Foreign Language Annals, 13, 191-199. https://doi.org/10.1111/j.1944-9720.1980.tb00751.x

Le, T. (2002). TESOL Courseware, theories of first language learning (WWW Documents). School of Education, University of Tasmania.

Levy, M. (2009). Technologies in use for second language learning. The Modern Language Journal, 93, 769-782. https://doi.org/10.1111/j.1540-4781.2009.00972.x

Morgan, C. (1993). Teaching culture at A-level. Language Learning Journal, 7, 42-44. https://doi.org/10.1080/09571739385200121

Pesola, A. (1991). Culture in the elementary school foreign language classroom. Foreign Language Annals, 24, 331-346. https://doi.org/10.1111/j.1944-9720.1991.tb00478.x

Prodromou, L. (1992). What culture? Which culture? Cross-cultural factors in language learning. ELT, 46(1), 39-50. https://doi.org/10.1093/elt/46.1.39 
Robinson, N. (1985). Cross-cultural understanding. New York: Pergamon Press.

Seelye, H. (1994). Teaching culture: Strategies for intercultural communication (3rd ed.). Lincolnwood, Ill: National Textbook Co.

Syahrom, A. (1995). Encounter of the cultural kind. A paper presented in the THAI TESOL Conference, January 1995.

Timmis, I. (2002). Native-speaker norms and international English: A classroom view. ELT Journal, 56(3), 240-249. https://doi.org/10.1093/elt/56.3.240

\section{Copyrights}

Copyright for this article is retained by the author, with first publication rights granted to the journal.

This is an open-access article distributed under the terms and conditions of the Creative Commons Attribution license (http://creativecommons.org/licenses/by/4.0/). 